Case Reports in
Gastroenterology
Case Rep Gastroenterol 2020;14:472-476

DOI: $10.1159 / 000509500$

Published online: October 8, 2020

(C) 2020 The Author(s)

Published by S. Karger AG, Basel www.karger.com/crg

This article is licensed under the Creative Commons Attribution-NonCommercial 4.0 International License (CC BY-NC) (http://www.karger.com/Services/OpenAccessLicense). Usage and distribution for commercial purposes requires written permission.

\title{
Amoxycillin-Clavulanic Acid-Induced Esophageal Ulcer: An Unusual Cause
}

\author{
Apichat Kaewdech $^{\mathrm{a}} \quad$ Tanawat Pattarapuntakul $^{\mathrm{b}} \quad$ Pimsiri Sripongpun $^{\mathrm{a}}$ \\ aGastroenterology and Hepatology Unit, Department of Medicine, Faculty of Medicine, \\ Prince of Songkla University, Songkhla, Thailand; bNKC Institute of Gastroenterology and \\ Hepatology, Songklanagarind Hospital, Prince of Songkla University, Songkhla, Thailand
}

\section{Keywords}

Drug · Endoscopy · Esophagitis · Esophagus

\begin{abstract}
Pill-induced esophagitis or esophageal ulcers are considered when patients have retrosternal chest pain or odynophagia following the ingestion of suspicious medications. Various drugs have been reported to induce esophageal ulcers. However, amoxycillin-clavulanic acid-induced esophagitis or esophageal ulcer has not been reported in literature. Hence, we report the case of a 30-year-old Thai male who presented with acute, severe odynophagia and retrosternal chest pain. He had a history of taking amoxycillin-clavulanic acid for 12 days. An esophagogastroduodenoscopy was performed and revealed geographic clean-based ulcers, with a kissing-ulcer appearance at the level of the mid-esophagus. A biopsy was taken and revealed inflamed granulation tissue and an ulcer with neither infection nor malignancy. Thus, the diagnosis of an amoxycillin-clavulanic acid-induced esophageal ulcer was made according to the clinicopathologic report.

(c) 2020 The Author(s)

Published by S. Karger AG, Basel
\end{abstract}

\section{Introduction}

Pill-induced esophagitis or ulcers, were first mentioned in 1970 by Pemberton [1]. At present, there are many cases of drug- or pill-induced esophagitis, or more severe forms such as an esophageal ulcer [2]. A variety of medications including antibiotics, non-steroidal anti- 


\section{Case Reports in Gastroenterology}

\begin{tabular}{l|l}
\hline Case Rep Gastroenterol 2020;14:472-476 \\
\hline DOI: 10.1159/000509500 & $\begin{array}{l}\text { ○ 2020 The Author(s). Published by S. Karger AG, Basel } \\
\text { www.karger.com/crg }\end{array}$ \\
\hline
\end{tabular}

Kaewdech et al.: Amoxycillin-Clavulanic Acid-Induced Esophageal Ulcer

inflammatory drugs, bisphosphonates, ascorbic acid, potassium chloride, ferrous sulfate, acetaminophen, warfarin, and chemotherapeutic regimens have been reported as causing esophagitis or ulcers [3-5]. Antibiotics are the most common etiology, and well-recognized antibiotics that can cause pill-induced esophagitis/ulcer are: doxycycline [6], clindamycin [7], cloxacillin [8], or rifampicin [9].

However, from our literary research, there has been no report of amoxycillin-clavulanic acid associated with esophagitis or esophageal ulcers. Therefore, we aimed to summarize the case of a patient with an esophageal ulcer linked to the ingestion of amoxycillin-clavulanic acid.

\section{Case Presentation}

A 30-year-old Thai male doctor without any underlying disease presented with odynophagia and retrosternal chest pain after taking amoxycillin-clavulanic acid for 12 days. Twelve days prior to this presentation, he was diagnosed with infected acne vulgaris at his upper chest, and amoxycillin-clavulanic acid (875/125 mg per tab) to be taken twice a day was prescribed as treatment for his condition. He denied taking any other medications, and his past medication history was unremarkable. Soon after the onset of symptoms, he took sucralfate syrup, $1 \mathrm{~g}$, four times a day, for 3 days. However, his clinical condition did not improve, and he still experienced odynophagia as well as severe retrosternal chest pain while eating.

Upon physical examination, his body temperature was $36.7^{\circ} \mathrm{C}$, pulse rate $74 \mathrm{bpm}$, blood pressure $120 / 80 \mathrm{~mm} \mathrm{Hg}$, and respiratory rate 18 breaths per minute. There was neither a pale conjunctiva nor an icteric sclera. Abdominal examination revealed no abdominal distension, normal bowel sounds, and his liver and spleen were not palpable. The laboratory test revealed hematocrit 46.7\%, white blood cell counts $8.61 \times 10^{\%} / \mathrm{L}$, PMN $47.2 \%$, lymphocyte $46.3 \%$, and platelet count $268 \times 10^{9} / \mathrm{L}$. He then underwent an esophagogastroduodenoscopy (EGD), which showed multiple geographic, clean-based ulcers between 30 and $35 \mathrm{~cm}$ from an incisor, with a kissing-ulcer-like appearance (Fig. 1). A biopsy was taken at the esophageal ulcer.

Histopathology of the biopsy specimens was consistent with an ulcer and inflamed granulation tissue with exudate (Fig. 2), but without abnormal cells or viral inclusion bodies. Hence, a pill-induced esophageal ulcer was diagnosed from a combination of his clinical condition, EGD findings, and the histopathological report.

Apart from stopping amoxycillin-clavulanic acid, he continued sucralfate four times daily, and proton-pump inhibitors, once a day, were initiated. A few days later, he felt better, and both his odynophagia and chest pain symptoms had improved. He did not undergo a followup endoscopy.

\section{Discussion}

This is the first case report of an amoxycillin-clavulanic-induced esophageal ulcer. We carried out a bibliographic search using the PubMed database with the keywords "pill-induced esophagitis" and "amoxycillin-clavulanic acid." However, there has been no case report reporting this condition. Hence, we here describe a case of an amoxycillin-clavulanic acid-associated esophageal ulcer.

Our case is consistent with pill-induced esophageal ulcers, based on a clinical presentation of odynophagia and chest pain in a patient with a history of taking amoxycillin-clavulanic acid. The endoscopic findings showed the hallmark feature of kissing ulcers at the mid-esophagus as well as histology revealing inflamed granulation tissue without infection. 


\section{Case Reports in Gastroenterology}

\begin{tabular}{l|l}
\hline Case Rep Gastroenterol 2020;14:472-476 \\
\hline DOI: 10.1159/000509500 & $\begin{array}{l}\text { @ 2020 The Author(s). Published by S. Karger AG, Basel } \\
\text { www.karger.com/crg }\end{array}$ \\
\hline
\end{tabular}

Kaewdech et al.: Amoxycillin-Clavulanic Acid-Induced Esophageal Ulcer

Amoxycillin-clavulanic acid is a combined oral antibiotic, which was first launched in 1981 for the treatment of beta-lactamase-producing bacteria [10]. It is commonly used for patients with respiratory tract infections, or skin and soft tissue infections. Although high tolerability has been observed for this medication, there have been some safety concerns concerning its usage, such as gastrointestinal side effects including diarrhea and drug-induced liver injury. However, to date, there has been no reported of a case of pill-induced esophagitis caused by amoxycillin-clavulanic acid.

According to the literature, there are two factors correlated with medication-induced esophageal injury: drug factors and patient factors. For instance, there are four mechanisms, which affect the esophageal wall [2]. Firstly, the acidity of medication; secondly, alkaline property; thirdly, high osmolarity of medication; and lastly, direct injury through the esophageal wall. To our knowledge, there is no known exact mechanism of amoxycillin-clavulanic acidinduced ulcer in the esophagus. Due to the large size of the pill and the acidic properties of clavulanic acid, we hypothesized that it could have directly injured the mucosa of the esophageal wall. Regarding patient factors, there are predisposing factors associated with this condition, although underlying disease of motility disorders or esophageal tumors are expected to increase complications [2]. Apart from that, our case had no risk factors; except for drinking small amounts of water and consuming drugs in a recumbent position, which may be a precipitating cause as the recumbent position may promote the pill to remain in the esophagus where it would be prone to irritate the esophageal mucosa.

Endoscopy of our case demonstrated a typical esophageal ulcer at the mid-esophagus, which is consistent with medication-induced esophagitis $[3,4,11,12]$. The mid-esophagus is the most common site of injury due to its anatomical narrowing from aortic arch compression [2], and so pills may be easily retained in this area. Although a Kissing ulcer was observed in our patient, which is typical of an endoscopic finding, this has only been found in $8 \%$ of the patients undergoing endoscopy [12]. Conversely, among biopsy-proven histopathology, this has correlated with a kissing-ulcer in $77 \%$ of cases [13].

Histopathology revealed no evidence of infection, including herpes or cytomegalovirus. Drug-induced esophagitis revealing eosinophilic infiltration at the epithelium is uncommon and only found $14 \%$ of the patients [13]. Nevertheless, diagnosis was made by clinicopathologic evidence.

Pill-induced esophagitis or ulcers are a self-limiting condition [3], whereas stopping causative medication is the mainstay of treatment. Treatment with antacids, histamine- 2 receptor antagonists, proton-pump inhibitors, or sucralfate are reported for relieving symptoms in these patients [4]. Follow-up endoscopy may not necessarily be required unless there is no improvement of symptoms.

\section{Acknowledgement}

We would like to thank Dr. Poowadon Wetwittayakhlung, a pathologist, who kindly provided the photographs of the patient's histopathological findings.

\section{Statement of Ethics}

Informed consent was obtained for this case report. This case report was conducted ethically in accordance with the World Medical Association Declaration of Helsinki. 
Conflict of Interest Statement

The authors have no conflicts of interest to disclose.

\section{Funding Sources}

There are no funding sources to report.

\section{Author Contributions}

Guarantor of the article: A. Kaewdech

A. Kaewdech, T. Pattarapuntakul, and P. Sripongpun made substantial contributions in drafting the manuscript, critical revisions, and final manuscript approval.

\section{References}

1 Pemberton J. Oesophageal obstruction and ulceration caused by oral potassium therapy. Br Heart J. 1970 Mar;32(2):267-8.

2 Zografos GN, Georgiadou D, Thomas D, Kaltsas G, Digalakis M. Drug-induced esophagitis. Dis Esophagus. 2009;22(8):633-7.

3 Dağ MS, Öztürk ZA, Akın I, Tutar E, Clkman Ö, Gülșen MT. Drug-induced esophageal ulcers: case series and the review of the literature. Turk J Gastroenterol. 2014 Apr;25(2):180-4.

4 Jaspersen D. Drug-induced oesophageal disorders: pathogenesis, incidence, prevention and management. Drug Saf. 2000 Mar;22(3):237-49.

5 Kikendall JW, Friedman AC, Oyewole MA, Fleischer D, Johnson LF. Pill-induced esophageal injury. Case reports and review of the medical literature. Dig Dis Sci. 1983 Feb;28(2):174-82.

6 Amendola MA, Spera TD. Doxycycline-induced esophagitis. JAMA. 1985 Feb;253(7):1009-11.

7 Bestari MB, Agustanti N, Abdurachman SA. Clindamycin-Induced Esophageal Injury: Is It an Underdiagnosed Entity? Clin Med Insights Case Rep. 2019 Dec;12:1179547619884055.

8 Zezos P, Harel Z, Saibil F. Cloxacillin: A New Cause of Pill-Induced Esophagitis. Can J Gastroenterol Hepatol. 2016;2016:2904256.

9 Smith SJ, Lee AJ, Maddix DS, Chow AW. Pill-induced esophagitis caused by oral rifampin. Ann Pharmacother. 1999 Jan;33(1):27-31.

10 Geddes AM, Klugman KP, Rolinson GN. Introduction: historical perspective and development of amoxicillin/clavulanate. Int J Antimicrob Agents. 2007 Dec;30 Suppl 2:S109-12.

11 Kim SH, Jeong JB, Kim JW, Koh SJ, Kim BG, Lee KL, et al. Clinical and endoscopic characteristics of drug-induced esophagitis. World J Gastroenterol. 2014 Aug;20(31):10994-9.

12 Abid S, Mumtaz K, Jafri W, Hamid S, Abbas Z, Shah HA, et al. Pill-induced esophageal injury: endoscopic features and clinical outcomes. Endoscopy. 2005 Aug;37(8):740-4.

13 Kim JW, Kim BG, Kim SH, Kim W, Lee KL, Byeon SJ, et al. Histomorphological and Immunophenotypic Features of Pill-Induced Esophagitis. PLoS One. 2015 Jun;10(6):e0128110. 
Case Reports in Gastroenterology
Case Rep Gastroenterol 2020;14:472-476

DOI: $10.1159 / 000509500$

(c) 2020 The Author(s). Published by S. Karger AG, Basel www.karger.com/crg

Kaewdech et al:: Amoxycillin-Clavulanic Acid-Induced Esophageal Ulcer

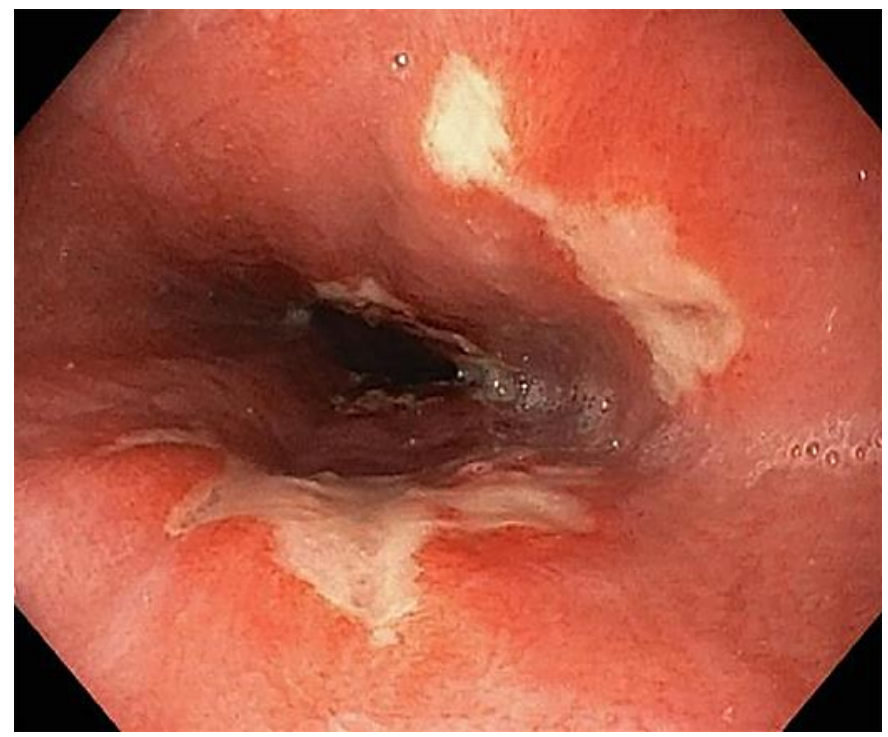

Fig. 1. EGD showing multiple geographic, clean-based ulcers between 30 and $35 \mathrm{~cm}$ from an incisor, with a kissing ulcer-like appearance.
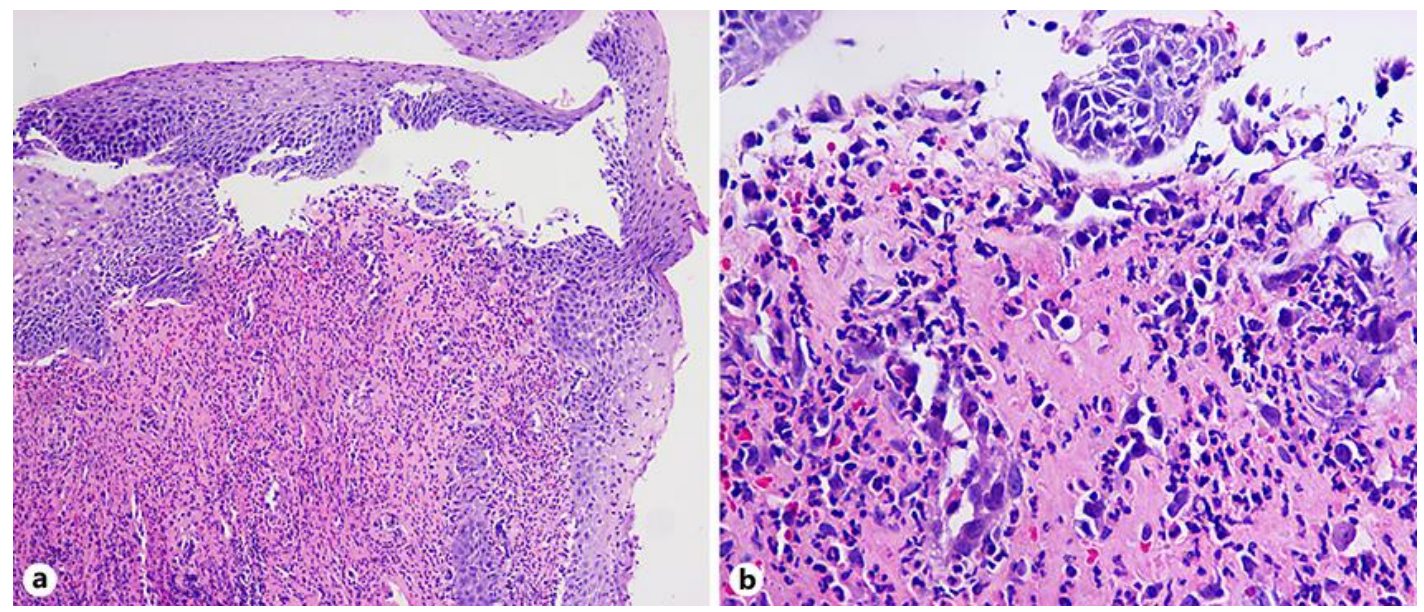

Fig. 2. H\&E stain showing granulation tissue with an ulcer of the esophageal wall $(a)(\times 100)$ and acute inflammation of the mucosa and submucosa in the esophageal wall (b) $(\times 400)$. 